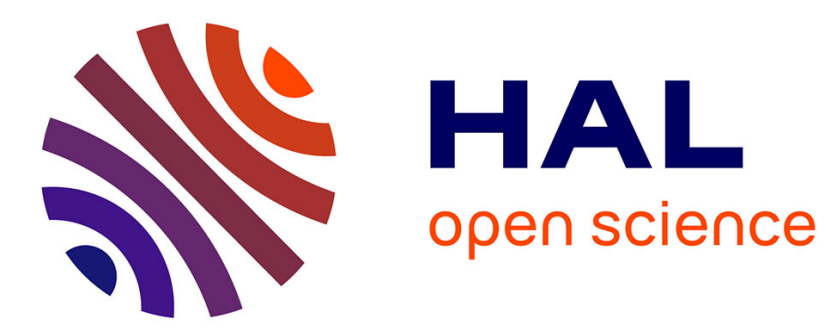

\title{
Open access and document supply
}

Joachim Schöpfel

\section{To cite this version:}

Joachim Schöpfel. Open access and document supply. Interlending and Document Supply, 2014, 42 (4), pp.187-195. 10.1108/ILDS-10-2014-0049 . sic_01083775

\section{HAL Id: sic_01083775 \\ https://archivesic.ccsd.cnrs.fr/sic_01083775}

Submitted on 29 Jul 2015

HAL is a multi-disciplinary open access archive for the deposit and dissemination of scientific research documents, whether they are published or not. The documents may come from teaching and research institutions in France or abroad, or from public or private research centers.
L'archive ouverte pluridisciplinaire HAL, est destinée au dépôt et à la diffusion de documents scientifiques de niveau recherche, publiés ou non, émanant des établissements d'enseignement et de recherche français ou étrangers, des laboratoires publics ou privés. 


\section{Document Supply and Open Access}

Purpose:The paper provides an overview and update of what we actually know about the impact of open access on inter-lending and document supply.

Approach:A review of recent papers, published after the Berlin Declaration on Open Access in 2003.

Findings:Everything seems to oppose document supply and open access. Open access has contributed to the recent decline of ILL and document supply requests but is not the only reason and probably not the most important. Open repositories and open access journals have the potential to substitute ILL and documentsupply; yet for different reasons, including legal compliance, this substitution remains of limited interest. ILL and document supply institutions have started to integrate open access into their workflow and service provision in different ways, and the paper provides a conceptual framework with some perspectives for further service development.

Originality:Paradoxically, relatively few papers make the link between open access and document supply, with empirical and/or conceptual elements. This paperproposes a synthesis and opens perspectives for future development and research.

\section{Perfect strangers (introduction)}

Everything seems to oppose document supply and open access. Open access is direct communication between the author and the reader, with a minimum of mediation and tools and a short value chain, while document supply introduces added value mediation into the value chain of scientific communication. Finding material in open repositories, especially via Google, seems to be a cost-effective alternative to paid document supply; in other words, open access is free while document supply is not. Open access implies profusion of information and equity of access and availability while document supply is a response to information scarcity and inequality. Open access is a matter of digital natives, closely related to the success of the Web, Google and social media, where document supply reaches back to the Gutenberg era and Xerox. Regarding reuse, open access tends to maximise reuse rights ("libre" open access) while document supply conditions often make reuse difficult if not impossible. Document supply is client-centred service while open access shifts the focus on the supply-side and the producer. And last but not least, open access is trendy while document supply attracts much less attention.

There is only one point where open access and document supply appear rather similar publishers generally do not like either of them, at least so far they cannot enforce their own playing rules, like embargos, digital rights management (DRM) or article processing charges (APC).

Document supply is an answer to a question, a service responding to a specific demand. But is the question still on the agenda? The reference texts on open access do not mention document supply, as if the brave new world of open science has no place for such oldfashioned and outdated mediation. On the other side, document supply services often consider open access as a threat rather than an opportunity (see for instance Mangiaracina et al. 2014)or they simply pretend to ignore it. The same institution may develop a brand new open access strategy while continuing document supply just as before, as a kind of historical legacy from the $20^{\text {th }}$ century, "as long as there is a demand", e.g. with decreasing funding and less resources.

Sometimes there simply is no apparent link between both services, such as in the National Library of Sweden (Hagerlid 2011) or other major STI centres (Schöpfel \& Prost 2009). Yet, 
from a functional viewpoint, both, document supply and open access, have some common goals, in particular to provide the scientific community with good and rapid information. IFLA's Lyon declaration launched during the 2014 World Library and Information Congress states that access to information plays a critical role in supporting development ${ }^{1}$. On this playing field, document supply and open access are similar rather than complementary or opposed, so that they can either compete or join their forces. But do they? And if so, how do they do it? Is open access an alternative to document supply?

Four years ago, we already asked if the movement for open access offered analternative to document supply, through non-mediated, directcommunication between scientific communities (a kind ofresearch P2P) and came to the conclusion that it did not, at least not in the French context, for various reasons including a too small number of available items, inadequacy between offer and demand, missing full text and access restrictions (Schöpfel \& Gillet 2011). Is it still so? Are the 2011 arguments still valid? Or has the situation changed?

In order to answer to this question, the following article reviews empirical studies and other papers on open access and document supply published between 2004 and 2013, in the aftermath of the Berlin Declaration on Open Access to Scientific Knowledge in 2003 ${ }^{2}$. Based on this review, we discuss some aspects on the relationship between open access and document supply, in particular:

- The lack of papers linking open access and document supply;

- The actual evidence on the impact of open access on document supply requests;

- The potential of open access resources for document supply;

- Legal problems with open access;

- The development of document supply services.

We will not exclude interlibrary loan of returnables (ILL) but put the focus on one way delivery of reproductions (copies, files) which corresponds best to the requests and downloading of open access items.

\section{On the dark side of the road}

As a matter of fact, open access is trendy while document supply is not. Searching for "open access" with the Google search engine will produce several million pages, much more than searching for "document supply" and "document delivery". The same search with Google Scholar in the field of academic publishing will produce the same result - nearly 18,000 papers are clearly dedicated to open access while the number for papers on document supply and delivery is significantly lower. Browsing through ScienceDirect or EmeraldInsight confirms this gap.

Open access is on the agenda, and it is a part of frontline research in library and information sciences. There are lots of news, opinion papers, surveys and other enquiries on open access, on projects, realisations, success stories and key factors, on business models and different options, such as green and gold road. ${ }^{3}$ If you want to increase the number of followers on Twitter, do not submit tweets on document supply (there aren't many) but focus on open science, open data and open access. There is a buzz on the social Web, a neverending stream of debates, controversies and exchanges, and there are several events such as open access weeks, conferences, seminars etc. Also, open access has entered the LIS B.A. and Master programs. National governments are investing in open access, and the European Commission is providing funding for research, infrastructure development and policy support in the field of open access.

\footnotetext{
${ }^{1}$ http://www.lyondeclaration.org/

2http://oa.mpg.de/lang/en-uk/berlin-prozess/berliner-erklarung/

${ }^{3}$ Green road $=$ self-archiving in open repositories. Gold road = publishing in open access journals.
} 
And document supply? Of course, there are still some papers on new ILL systems, some marketing surveys, some case studies on how to do document supply and ILL published in a small number of journals and very few books. There is still an IFLA section with annual events. But they do not attract much attention outside of a relatively small "ILDS community". It is just as if document supply was suddenly standing on the dark side of the road. Did anybody recently try to get public funding for research on document supply? Even the "eye of Sauron" appears to look in another direction, as particularly STM publishers seem to pay less attention to traditional document suppliers, compared to past years and the new challenges of open access, open data and research evaluation.

However, even more surprising is the fact that the number of studies making the link between open access and document supply is low, as if document supply shifted out of scope in the emerging landscape of open access to scientific information. As a result, any analysis of the link between open access and document supply still lacks feedback from operating experience and remains partly exploratory and speculative. On the institutional level, this situation sometimes gives the impression of a kind of lobotomized approach to information services where both services are disconnected from each other, without communication and common strategy ${ }^{4}$. This is neither helpful nor satisfying, for both services.

\section{Down and out?}

It is generally admitted and it is a common idea that document supply does decrease and will continue to do so. Some empirical studies confirm this idea. For instance, Koyama et al. (2011) report declining figures of ILL photocopy requests in Japan between 1994 and 2008. Our own statistics on French ILL and document supply has shown a significant downside trend since 2000 (Schöpfel \& Gillet 2011). Belgian colleagues from the Impala network predict, "document supply will be further reduced" (Corthouts et al. 2011, p.209).

What is the reason for this? At first sight it is open access, of course - increasing the amounts of material that can be found directly and freely via search engines (McGrath 2011, p.214). All sorts of open access publications and book digitising services will make users less dependent on ILL and document supply, say Corthouts et al. (2011). Cimen (2012) expects that open access journals and open repositories will be a serious alternative to traditional resource sharing methods in Turkish academic institutions (p.148).

However, a closer look on these and other papers reveals little empirical evidence for this causal relation and a situation that is a bit more complicated.

First of all, open access is not the only "usual suspect". Open access impacts document supply orders only insofar as it contributes to increasing availability of online resources. The other suspect is licensed content, subscriptions to online journals and e-books, especially in the form of large packages and big deals. "Increasing availability of e-content on a large scale through institutional services and open access (is) one major challenge for the sustainability of document supply services" says Appleyard (2010) from the British Library Document Supply Centre in Boston Spa. In quite a different context - China - Jia (2010) comes to the same conclusion that the convergence of big deals and availability of open access materials may lead to a decline of document supply (p.156).

Another point is that this effect is not mechanical. Depending on the context, all types of documents are not affected in the same way. In Japan for instance, because of big deal contracts between Elsevier and academic libraries, the decrease of photocopy requests mainly affects foreign journals, in particular those published by Elsevier, while the impact of institutional repositories, especially by digitization programs for domestic academic journals (departmental bulletins), seems marginal (Koyama et al. 2011) so far. Not green but gold road

\footnotetext{
${ }^{4}$ See for instance Burns (2014).
} 
affects document supply most. Cimen (2012) shares this idea - as universities publish content more and more via their own open access gold road journals, they do not need to sell copies of their articles. Schöpfel \& Soukouya (2013) describe a similar situation in Sub-Saharan Togo where a future digitizing program linked to an open repository should reduce problems with ILL of local $\mathrm{PhD}$ theses.

The project manager at the California Digital Library, Perry Willett (2009) observes that because of mass digitization projects some services have dropped, especially photocopies (non-returnables) while others increased, such as interlibrary book lending. Those items not in the public domain are only partly available on the web, in the form of snippets, and snippets may be good enough for citations but not for reading ${ }^{5}$. He adds that the massive digitization of public domain items will finally have no or very low impact on document supply because the majority of document supply requests is for more recent items and not for items in the public domain. Other variables that may diminish the effect of open access are low visibility, undeveloped indexing and missing search facilities. "Even though open access materials are freely available on the Internet, library users still request them through interlibrary loan" (Baich 2012, p.55). Is this just a kind of transitional information (mis-)behaviour? The future will tell.

Sometimes document supply does not decrease but remains stable. This is the case with the Italian Network for Interlibrary Document Exchange (NILDE), at least for the period 20052009. Here, $80 \%$ requests are for articles published within the current or last year, a time span most often under embargo in open repositories. For this reason, the authors are rather sceptical regarding the negative effect from open access on document supply (Bernardini \& Mangiaracina 2011). For them, the real threat is big deals with large numbers of electronic subscriptions - but only insofar as they become available in many institutions simultaneously, through consortia purchasing (p.21).

Is document supply down and out because of open access? Not yet. Goldner \& Birch (2012) state that " (...) research sharing has been opened up to a free market economy that consists not only of library suppliers, but also alternative suppliers that have joined the marketplace" (p.7), and they insist that the problem of document supply is not open access but pricing (buy or borrow?), budget (public funding) and law, in particular for international ILL.

\section{You can get it all (really?)}

The strength of traditional document suppliers is their detailed knowledge of the customers' needs, a crucial factor for acquisition policy, networking and resource sharing. Can open access substitute document supply? Can it satisfy the needs of document supply customers and end users? Has direct scientific communication via open repositories and open access journals the potential to replace document supply through non-mediated access to information?

For all we know today, the answer is yes, it can but only partly, while the future potential depends on the further development of the open access movement and especially on two key aspects, e.g. the mandatory policies of funding organizations and academic institutions, and the number of papers published in open access journals, with or without APC (gold road).

How many resources are there available in open access? The Directory of Open Access Repositories OpenDOAR ${ }^{6}$ contains more than 2,700 open repositories but the real number is certainly higher. Most of them are run by universities, faculties, departments, laboratories or other research institutions, for instance by the MIT, Columbia University or Harvard, while others are disciplinary, cross-institutional subject repositories. Open repositories cover all

\footnotetext{
${ }^{5}$ The same kind of argument was used by Google for their fair use claim.

${ }^{6}$ http://www.opendoar.org
} 
disciplines, and they contain all document types, mostly articles but also theses and dissertations, reports, conference proceedings, unpublished working papers etc.

The Directory of Open Access Journals $\left(\mathrm{DOAJ}^{7}\right.$ ) lists about 10,000 journals that do not charge readers or their institutions for access and that assign the rights of users to "read, download, copy, distribute, print, search, or link to the full texts of these articles", that exercise peer-review or editorial quality control and that report primary results of research or overviews of research results to a scholarly community.

Nobody can say exactly how many scientific papers are available in open access and which part of all scientific output they represent. The Bielefeld Academic Search Engine ${ }^{8}$ indexes nearly 65 million scientific open access web resources. Some studies claim a percentage of up to $50 \%$ published articles available in open access, green and gold road cumulated while Stevan Harnad usually speaks of $30 \%$ scientific information available in gratis open access ${ }^{9}$. This figure differs from one discipline and institution to another. In some scientific fields such as Physics and Mathematics, open access has more success than in Humanities or in Chemistry. Some institutions and funding bodies decided on a mandatory approach that commits scientists to deposit publications in institutional repositories and/or to publish in open access journals.

First statement: document supply services, especially when sharing resources and working with a network of back-up libraries, are able to satisfy more than $90 \%$ of incoming requests not only articles but all kinds of documents. This is much more than the actual potential of open repositories and of what open access journals can offer. Two key aspects could change the situation: (1) a generalization of mandatory policies by universities, research organizations and funding bodies which could push the part of institutional output in open access up to 60$90 \%$; (2) a globalization of open access journal publishing (gold road) as the dominant business model of academic publishing. In the short term, both options are not realistic.

Two aspects further limit the interest of open access for document supply. A growing number of items in open repositories are metadata without full text while other documents are under embargo or available only on Intranet (on campus). In particular, embargo periods of 12 to 24 months or more, enforced by publishers, are embarrassing because a large part of document supply requests deals with recent papers. Also, the growing percentage of scientific heritage materials in open repositories (journal back-files, older book collections, theses...) is not really interesting for document supply, for the same reason.

One example: about $75 \%$ of the HathiTrust books are not in the public domain which means that they are text searchable but must be ordered through traditional resource sharing methods for reading. As a result, "the ILL department will continue to play an intermediary role as long as patrons find it difficult to search and obtain what they need" (Eden \& Beaubien 2012).

Another example: UK PubMed Central was launched by the UK's eight principal funding bodies of biomedical and health research to provide free, open access to research results. In fact, less than $10 \%$ of the 20 million records are linked to free, available full text, and this is generally older material (Davey 2010).

Two other aspects touch specific categories of document supply customers. First, some customers ask for reliable quality content. In terms of journal publishing, this means the version of record. Yet, open repositories often contain (also) other versions, or non-reviewed papers. This may be acceptable for some information needs, for others it may not ${ }^{10}$. Secondly,

\footnotetext{
${ }^{7}$ http://doaj.org

${ }^{8}$ http://www.base-search.net

${ }^{9}$ Listserv GOAL, September 2014.

${ }^{10} \mathrm{We}$ will not speak here about so-called predatory publishing of open access journals which increases concerns on quality of open access content (see Beall 2012).
} 
customers especially in sensitive R\&D sectors like pharmacy, high tech or transport industry ask for secured access and guarantee for confidential order processing. Yet, open access multiplies access points, and non-mediated searching and downloading of items in open repositories and open access journal servers leave several traces on the Internet - interesting traces for economic intelligence but not always acceptable for customers.

\section{Don't worry, be happy}

Academic librarians consider copyright as one of the major challenges that will affect document supply operations in the near future (Massie 2012). This is no surprise. In many countries, national laws restrictthe possibility, for libraries and information centres, to reproduce and communicate scientific articles, books, dissertations, reports and other items, in order to protect intellectual property rights. Academic publishers especially in science, technology and medicine, succeeded through lobbying, negotiations and lawsuits to reduce if not prevent modern document supply in different countries ${ }^{11}$. In France, an author won his case against the French copyright centre CFC and the public research council CNRS in the court of final appeal ${ }^{12}$ and this put on ice the French document supply service RefDoc.

Document supply customers do not like trouble with copyright. They want copyrightcleared items. Also, they ask for reuse rights, for internal reproduction, dissemination and storage, more rights than the publishers' digital rights management conditions generally allocate. In this situation, open access may appear to be the solution of choice because "open access documents are freely available for everybody". Is this so? Of course not, and for various reasons.

First of all, the reuse rights of open access resources range from liberal licensing ("free" open access via CC-BY, for instance ${ }^{13}$ ) to interdiction of any "commercial" use, whatever this may be. For other documents on open access servers, terms and conditions are simply missing, and users/customers must or should check the legal conditions in the country of origin, which means they take risks. This is something documents supply customers generally do not like either. Not only for the corporate sector but also for the public R\&D, "gratis" open access is no solution as it often just only allows access to the needed resource but no usage for any "commercial purposes", e.g. activity "that is primarily intended for or directed toward commercial advantage or private monetary compensation"14.

Second reason: sometimes, especially in open repositories and social networks, the status of deposited items may be uncertain. The reader may remember Elsevier's takedown notices issued to Academia.edu, other networks and repositories and authors in 2013. Moreover, some deposits may contain material protected by third party rights. The problem is that, contrary to document suppliers, neither repositories nor social networks provide copyright clearance. The users/customers take on all the risk.

Third reason: a growing part of open access content in open repositories is neither free nor gratis but under embargo or restricted to authorized users, which often means on-campus access only (Prost \& Schöpfel 2014). Here, legal considerations and restrictions indirectly reduce the interest of open access as a substitute for document supply, in a double way - not only is one part of the "open" content not available at all but what is more, these access restrictions mainly affect the most recent items which are those most requested in document supply.

\footnotetext{
${ }^{11}$ See for instance the recent court victory of Elsevier, Springer and Thieme against the document supply service of the ETH Zurich in Switzerland, a kind of distant echo of the former STM lawsuits levied against the German Subito service.

${ }^{12}$ Court of Cassation, 11 December 2013

${ }^{13}$ See Neylon (2012).

${ }^{14}$ http://creativecommons.org/weblog/entry/17127
} 
From the viewpoint of document supply, it may be particularly interesting to check the guidelines by SPARC, PLOS and OASPA on different degrees of openness ${ }^{15}$ against information needs and practice of usual document supply customers. Perhaps in the future standardized metadata elements on access and license information will reduce the risk and facilitate the identification of available items (Neylon et al. 2014). However, they will not reduce the access and usage restrictions themselves.

So far, we have considered the legal aspects of open access as a substitute for document supply for the end user. But what about open access items as a resource for document supply? Can academic libraries or information centres legally provide their patrons and customers with open access items, e.g. articles, theses or other documents they retrieved from open repositories or journals?

As is so often the case, the question may be easy while the answer is not. On the one hand, the answer depends on licensing issues, terms and conditions of the server where the document is retrieved. Again, the non-commercial condition (NC) will be a strong barrier to this kind of service. On the other hand, an ethical and political more than a legal debate opposes paid mediated delivery of open access items to direct access and downloading by the end user. In other words, can document suppliers legally provide documents that their authors explicitly share via open access? Should they? What is it that they can provide - URLs, unique identifiers, the files themselves?

And then, the last question is this: can they take money for this? For the content, for royalties (copyright), for the added value, for anything else? Or is open access supply necessarily gratis service?

For the moment, these questions remain open. Are there any good practices, guidelines or recommendations with more than local value?

One consequence of this situation can be that academic libraries and information centres withdraw from general document supply to traditional academic ILL limited to the public sector, to higher education and research organisations, while leaving the document supply business for industry, R\&D and private customers to corporate vendors and the publishers themselves, as B2B or B2P.

From a legal viewpoint, this would be a "clean solution". In a certain way, it would transform the document supply activity in a kind of Facebook community with friends, friends of friends, everyone and other groups, inside and outside, each with different access and usage rights. In a certain way, it would reflect liberal policy with a strict minimum of public service. Here at last, the legal question meets ethical issues and political choices (Posner 2012): is the library service a right for all citizens? Is resource-sharing part of the library's core service? Is information, especially library-mediated information, part of the common good? Today the tendency is, for legal as well as for political and financial reasons, to reduce the library outreach (including inter-lending and document supply) to the institution and the community, be it the campus, a research organisation or a Higher Education network. The rationale is: "Are there are legal problems with document supply? Let us stop it and focus on investment in open access". This may not be totally satisfying, neither for the traditional customers of document supply nor for the suppliers, but it is an option.

\section{Beginnings}

Another option is service development. Open access is here to stay. Today, scientific and technical information can be hidden behind pay walls, or it can be freely available on the Internet, or both. Open repositories and open access journals satisfy one part of the demand for scientific and technical information but do not replace document supply, for the reasons

\footnotetext{
${ }^{15}$ http://www.sparc.arl.org/resource/howopenisit
} 
indicated above. "Open" can have different meanings, and not all of them are adapted to information needs especially from corporate R\&D.The real challenge for document supply management is not strategic management, to decide whetheror not to continue, but to change management, to integrate open access as an opportunity for service development. Institutions do so in two ways ${ }^{16}$.

Horizontal integration: Some add open access as a secondary service to the basic core service of document supply. In other words, they add an open access offer to the existing ILL and/or document supply offer, e.g. they extend the range of their service without modifying the basic offer. For instance, they add an institutional repository, an open access platform for journals or other documents, a portal that gives access to open access resources or simply a page with links to freely available resources on the Internet.

Our survey a couple of years ago revealed that this (at least initially) was the dominant solution of major STI centres (Schöpfel \& Prost 2009). Billingham \& Chan (2012) describe the same approach for the document supply at Edith Cowan University, Perth, Australia. This was also the initial approach of the US Office for Scientific and Technical Information (OSTI) when it launched, together with other institutions, a large portal based on powerful federated search facilities covering selected sites of known quality (Warnick 2010) ${ }^{17}$. The underlying principle was free access to records connected to several document supply services but without links to available full text or information on open access. Another example of this "horizontal" service development is the proposal by Buchanan (2009) to transform ILL into a gateway service, using direct purchase, and guiding users to book trading sites, digital collections and other alternatives.

Vertical integration:Others integrate open access into their basic service, as a peripheral or complementary offer, optional or compulsory, visible or invisible. Here, open access is directly connected to document supply, and the basic core service itself is modified. Birch et al. (2013) report that academic libraries "are filling requests through the open access that the mass digitization projects have spawned. It can sometimes be a bit time consuming but it gives staff and patrons more variety. Library staff will now Google it or search open access sites" (p.15). Open access became part of the work. Sometimes, the document supply and ILL workflow starts with open access searching, on different levels - searching for articles with Google Scholar or PubMed Central, searching for journals with DOAJ, searching for books with Google Books, or simply searching on the Web with the Google general search engine. Another option is to start with searching systematically for electronic theses and dissertations in institutional repositories before sending a request to OCLC. This is necessary to enhance the service and "educate users about open access" (p.60), says Baich (2012) who however reminds also, that because of retrieval problems and limited access (embargos etc.) "ILL requests are unlikely to decrease as a result of increasing numbers of open access materials".

Based on a survey with UK ILL professionals, Johnson (2011) objects that "the use of open access materials as a resource for satisfying requests was fairly low" and that "it is unclear (...) if the coming months and years will see repositories and document supply services operate in tandem or in direct competition as sources of supply" (p.131). Two reasons for this are mentioned, the problem with different versions (preprint, published) and the problem with different sources - whereas gold open access journals are accepted because they offer formally published articles, green open repositories are sometimes rejected because of their uncertain quality. Yet, some customers accept preprint versions because they give preference to instant access over quality.

In Serbia, the ILL and document supply service at the Belgrade university library integrated open access discovery tools and open repositories into their ILL workflow in the

\footnotetext{
${ }^{16}$ See also the recent study by Hu \& Jiang (2014).

${ }^{17}$ WorldWideScience.org
} 
following, empirical way (Pavlovic\& Matutinovic 2010): requested items are searched first in the local library catalogue and digital library,then in institutional and other repositories, then in other European libraries, andfinally in other catalogues (WorldCat), portals (NDLTD) and search engines (Google Scholar, Google Books). If the document cannot be retrieved, the service tries to identify the author's address in order to obtain the document via direct contact.

This last example confirms that less demand does not necessarily mean less work. What all these initiatives have in common is that the retrieval process is part of the back office. Long tail items, especially when outside of traditional dissemination channels such as grey literature may be less easy to identify, locate and get. More sophisticated workflowswith several tools and sources will increase workload.This means, too, that most of the questions listed by Davidson (2009) have to be answered by the document supply staff: who has the item? Is it available? Is it available to the customer? At what cost? And so on.

Automation, e.g. more and deeper vertical integration is a way to increase efficiency in spite of growing workload and complexity. This can be done in different ways but for this paper, it is sufficient to define two options. On the one hand, a traditional library catalogue that informs on the records level (journal, book, article...) if the item is available via open access, linking to the site or to the full text. On the other hand, a metadata repository or portal linking by default to full text and offering the possibility to order the document via document supply, ILL,print-on-demand or even from commercial vendors (booksellers etc.) if the item is under embargo or otherwise not available or if the users/customers want a format different from the digital file, especially for books or theses.

This vertical integration offers a more or less unmediated document delivery provision, which is in line with some of the basic usual customer requests, such as to get a large range of information through simple discovery, in a timeliness manner. However, they generally also ask for valuable information (quality), for a guarantee of legal compliance and usability or reuse rights (Schöpfel \& Gillet 2007).

In so far as metadata contain the relevant information, automation can take into account these needs and propose customized peripheral and/or complimentary service provisions. For instance, copyright clearance and quality guarantee should be peripheral (obligatory, related to the core service of document delivery, non-optional) while the check for usability could be complimentary (optional). Yet, the published case studies do not describe any document supply service with this kind of service development.Document supply is at the beginnings, again.

Three comments to finish this section about service development.

Opportunity: As pointed out, some institutions adopt a horizontal approach while others choose a vertical integration; some do both or switch from the first to the second option. The common point of all is that they do not consider open access as a threat to document supply but as an opportunity to enhance the service quality. This means, too, that they consider open access with realism, not with aversion, ideology or evangelism.

New content and services:"With the increasing availability of OA resources and digital reference tools (...) the line between DSS and reference services is blurring... There is a need to combine both and also the need for DSS to extend into the knowledge objects contained in traditional documents" (Jia 2010, p.156). This may require the re-engineering of library service organization, workflows and staff capabilities. This may also contribute to further service development: customers not only ask for documents, they also need data, knowledge, intelligence about experts, institutions, projects and emerging fields. Open access is the opportunity for document supply to move towards open source intelligence, with far more added value than before.

New business models: "Information sharing is an integrated part of the R\&D process" (Warnick 2010, p.85). However, as Massie (2012) points out, the competition between 
publishers, Internet and open access, together with mass digitization projects and the management of print legacy collection will affect document supply and change the "craft" document supply. But not only willthe toolchange, but the whole business model is challenged by open access. The core of document supply is user-centred service, a reply to a specific information need, e.g. customized demand management, B2B. Open access follows quite a different logic and its dynamics are driven by production, by needs for impact, visibility and evaluation, with deep roots in P2P. The economics of document supply are changing, moving from demand management (Keynes) to supply-side economics wheresupply creates its own demand. It may be too early to grasp the whole implication of this change but the questions are on the agenda: can document supply be free (gratis), as free or gratis as open access? ${ }^{18}$ Can we speak of open document supply? Will the added value shift from document retrieval to selection and legal clearance of information? What exactly will be the paid service, and who will pay for it, the producer or the consumer?

\section{Survival (conclusion)}

Vital for research and development, scientific and technical information is not equally distributed. Some people have more access, others less. Some have time, tools and capacities to retrieve what they need by themselves, others not. Some information can be reused; others can only be viewed or read. Document supply is a way to cope with this situation and to contribute, as a for-profit business or as a public service, to information redistribution.

Internet and the Web foster direct communication. Open access introduces new opportunities. More information than ever before becomes available. But not all of this information is useful for document supply, not all of it corresponds to the customers' needs; and a significant part still remains hidden behind pay walls.As long as one part of the resources needed by public research and industrial $R \& D$ is not freely available for everyone, at every time and everywhere, there will always be a place and a demand on the market for the mediation of identification, retrieval and communication of research output.

In our "era of now" good enough beats perfection, as long as information needs are fulfilled instantaneously (Hinssen 2010). Retrieving information on the Web may be good enough to satisfy one part of the demand, even if "asking a scientist (...) to find information in his (their) field using common browsers is like asking a doctor to diagnose disease without X-rays" (Warnick 2010, p.86) ${ }^{19}$. Another part will be satisfied through big deals, article selling (pay-per-view) and APC-funded commercial open access (gold road), even if this forprofit publishing contributes to unequal distribution of scientific information, on both sides now, supply and demand.

Our review confirms that there is still a place for document supply services and that traditional document supply and ILL are already investing open access. More empirical feedback from the field is needed, together with marketing studies, best practices and economic analysis. Document suppliers will need to adjust and become knowledge or intelligence suppliers, with a larger spectrum of resources and sources, also with a higher degree of added value. The future will be more than just lending books and sending copies. The line between document supply and other, not only reference services will continue "blurring" (Jia 2010).

The basic question of document supply has remained unchanged for fifty years: who will redistributethe scarcity of vital resources? Who will assist public research and corporate R\&D to get the information they need?Our conviction is that this is and should bepart of the public service, to be delivered by academic libraries and governmental agencies. Open access acts

\footnotetext{
${ }^{18}$ Some institutions and networks already work without invoicing, at least within their scientific community.

${ }^{19}$ Baich (2012) reminds that Google Scholar has difficulties finding documents in institutional repositories because of limitations of Dublin Core and limited navigation on the site.
} 
like a catalyst. Will "my credit card (become) my library card" (Bean et al. 2012, p.47)? Will the public action be limited to fostering the supply side of open access, via repository infrastructure and APCs, leaving the satisfaction of information demands "to the market forces"? When in the past public ILL and document supply were downgraded or wrapped $u^{20}$, the reason was not open access but lack of funding, innovation and/or legal compliance. Perhaps the future will just be a "patchwork quilt (in) the continuity of existing systems" (loc.cit.), with low budgets and librarians trying as before to do their job as best as possible, in the service of their research communities. Perhaps, that will be just good enough.

PS. Don't let me be misunderstood. I love open access. But love should not be blind. Science is far too important and serious to accept any solution which is just good enough.

\section{Bibliography}

Appleyard, A. (2010), "British Library document supply - a fork in the road",Interlending \& Document Supply, vol.38, no. 1, pp. 12-16. Available: http://dx.doi.org/10.1108/02641611011025307

Baich, T. (2012), "Opening interlibrary loan to open access",Interlending \& Document Supply, vol. 40, no. 1, pp. 55-60. Available: http://dx.doi.org/10.1108/02641611211214305

Beall, J. (2012), "Predatory publishers are corrupting open access," Nature, vol. 489, no. 7415, p. 179. Available: http://dx.doi.org/10.1038/489179a

Bean, M., Nance, H., and Frederiksen, L. (2012), "Global resource sharing from a Pacific Northwest perspective",Interlending \& Document Supply, vol. 40, no. 1, pp. 43-48. Available: http://dx.doi.org/10.1108/02641611211214288

Bernardini, E., and Mangiaracina, S. (2011), "The relationship between ILL/document supply and journal subscriptions",Interlending \& Document Supply, vol. 39, no. 1, pp. 9-25. Available: http://dx.doi.org/10.1108/02641611111112101

Billingham, L., and Chan, J. (2012), "Research online, open access and document delivery", in ECU Research Week 2012, 17 - 21 September 2012. Available: http://ro.ecu.edu.au/creswk/31

Birch, K. J., Goldner, M., and Parson, K. N. (2013), "Seven degrees of interlibrary lending",Interlending \& Document Supply, vol.41, no. 1, pp. 12-17. Available: http://dx.doi.org/10.1108/02641611311313034

Buchanan, S. (2009), "Interlibrary loan is the new reference: reducing barriers, providing access and refining services",Interlending \& Document Supply, vol. 37, no. 4, pp. 168-170. Available: http://dx.doi.org/10.1108/02641610911006247

Burns, C. S. (2014), "Academic libraries and open access strategies", in Advances in Library Administration and Organization, Williams, D. E., and Golden, J., Eds. Bingley, Emerald, vol. 32, pp. 147-211.

Cimen, E. (2012), "Future of resource sharing in Turkey: can open access be an alternative?",Interlending \& Document Supply, vol. 40, no. 3, pp. 144-149. Available: http://dx.doi.org/10.1108/02641611211258217

Corthouts, J., Borm, J. V., and Eynde, M. V. (2011), "IMPALA 1991-2011: 20 years of ILL in Belgium",Interlending \& Document Supply, vol. 39, no. 2, pp. 101-110. Available: http://dx.doi.org/10.1108/02641611111138905

Davey, P. (2010), "UK PubMed Central: becoming the information resource of choice for the UK's life sciences research community",Interlending \& Document Supply, vol. 38, no. 2, pp. 102-107. Available: http://dx.doi.org/10.1108/02641611011047178

\footnotetext{
${ }^{20}$ For instance, ICIST, INIST, NIWI and SUBITO.
} 
Davidson, E. (2009), "How close are we to having a global 'get it for me' service?",Interlending \& Document Supply, vol.37, no. 2, pp. 64-67. Available: http://dx.doi.org/10.1108/02641610910962274

Eden, K., and Beaubien, A. K. (2012), "HathiTrust: digital access at the intersection of interlibrary lending potential and the protection of intellectual property rights",Interlending \& Document Supply, vol.40, no. 2, pp. 94-99. Available: http://dx.doi.org/10.1108/02641611211239560

Goldner, M., and Birch, K. (2012), "Resource sharing in a cloud computing age",Interlending \& Document Supply, vol.40, no. 1, pp. 4-11. Available: http://dx.doi.org/10.1108/02641611211214224

Hagerlid, J. (2001), "The role of the national library as a catalyst for an open access agenda: the experience in Sweden",Interlending \& Document Supply, vol. 39, no. 2, pp. 115-118. Available:http://dx.doi.org/10.1108/02641611111138923

Hinssen, P. (2010), The new normal: explore the limits of the digital world. Gent, Across Technology.

$\mathrm{Hu}, \mathrm{F}$., and Jiang, H. (2014), "Open access and document delivery services: a case study in Capital Normal University Library", Interlending \& Document Supply, vol. 42, no. 2/3, pp. 79-82. Available:http://dx.doi.org/10.1108/ILDS-01-2014-0003

Jia, P. (2010), "The development of document supply services in China",Interlending \& Document Supply, vol. 38, no. 3, pp. 152-157. Available: http://dx.doi.org/10.1108/02641611011072341

Johnson,G. J. (2011), "No fate but what we make? Current trends and challenges in the UK document supply community",Interlending \& Document Supply, vol. 39, no. 3, pp. 127133. Available: http://dx.doi.org/10.1108/02641611111164609

Koyama, K., Sato,Y., Tutiya, S., and Takeuchi,H. (2011),"How the digital era has transformed ILL services in Japanese university libraries: a comprehensive analysis of NACSIS-ILL transaction records from 1994 to 2008",Interlending \& Document Supply, vol. 39, no. 1, pp. 32-39. Available: http://dx.doi.org/10.1108/02641611111112129

Mangiaracina, S., Cocever, C., Chiandoni, M., and Arabito, S. (2014), "Assessing the effectiveness of a national resource sharing system", Interlending \& Document Supply, vol. 42, no. 2/3, pp. 98-104. Available:http://dx.doi.org/10.1108/ILDS-12-2013-0039

Massie, D. (2012),"Interlending trending: a look ahead from atop the data pile",Interlending \& Document Supply, vol.40, no. 2, pp. 125-130. Available: http://dx.doi.org/10.1108/02641611211239623

McGrath, M. (2011),"Ten years as editor of ILDS and 35 years in ILL and document supply: thoughts of the outgoing editor", Interlending \& Document Supply, vol. 39, no. 4, pp. 211216. Available: http://dx.doi.org/10.1108/02641611111187640

Neylon, C. (2012), "More than just access: Delivering on a networked-enabled literature", PLoS Biol, vol. 10, no. 10, pp. e1 $001417+$ Available: http://dx.doi.org/10.1371/journal.pbio.1001417

Neylon, C., Pentz, E., and Tananbaum, G. (2014), "Standardized metadata elements to identify access and license information," Information Standards Quarterly, vol. 26, no. 2, pp. 35+. Available: http://dx.doi.org/10.3789/isqv26no2.2014.07

Pavlovic, A., and Matutinovic,S. F. (2010), "Document supply today in Serbia: counterpoint to copyright",Interlending \& Document Supply, vol. 38, no. 4, pp. 210-217. Available: http://dx.doi.org/10.1108/02641611011094338

Posner, B. (2012), "The ethics of library resource sharing in the digital age",Interlending \& Document Supply, vol. 40, no. 2, pp. 119-124. Available: http://dx.doi.org/10.1108/02641611211239614 
Prost, H., and Schöpfel, J. (2014), "Degrees of openness. Access restrictions in institutional repositories," D-Lib Magazine, vol. 20, no. 7/8. Available: http://www.dlib.org/dlib/july14/prost/07prost.html

Schöpfel, J., and Gillet, J. (2007), "On document supply in the digital world",Interlending \& Document Supply, vol. 35, no. 4, pp. 195-204. Available: http://dx.doi.org/10.1108/02641610710837491

Schöpfel, J., and Prost, H. (2009), "Document supply of grey literature and open access: an update",Interlending \& Document Supply, vol. 37, no. 4, pp. 181-191. Available: http://dx.doi.org/10.1108/02641610911006274

Schöpfel, J., and Gillet, J. (2011), "Interlending and document supply in France 2010",Interlending \& Document Supply, vol. 39, no. 2, pp. 76-83. Available: http://dx.doi.org/10.1108/02641611111138860

Schöpfel, J., and Soukouya, M. (2013), "Providing access to electronic theses and dissertations. A case study from Togo",D-Lib Magazine, vol. 19, no. 11/12. Available: http://www.dlib.org/dlib/november13/schopfel/11schopfel.html

Warnick, W. (2010), "Federated search as a transformational technology enabling knowledge discovery: the role of WorldWideScience.org",Interlending \& Document Supply, vol. 38, no. 2, pp. 82-92. Available: http://dx.doi.org/10.1108/02641611011047150

Willett, P. (2009), "Mass digitization and its impact on interlending and document supply",Interlending \& Document Supply, vol. 37, no. 3, pp. 143-148. Available: http://dx.doi.org/10.1108/02641610910985620

All web sites visited in September 2014.

\section{The author}

Joachim Schöpfel is senior lecturer and former head of the department of information and document sciences at the Charles de Gaulle University of Lille 3 and researcher at the GERiiCO laboratory. He is also director of the French national reproduction centre for $\mathrm{PhD}$ theses (ANRT). He is interested in scientific information, academic publishing, open access, grey literature, usage statistics and service development. He is member of GreyNet and euroCRIS.

joachim.schopfel@univ-lille3.fr 